University of Nebraska - Lincoln

DigitalCommons@University of Nebraska - Lincoln

1961

\title{
Notes on Sanguinicola davisi (Trematoda: Sanguinicolidae) In the Gills of Trout
}

H. S. Davis

Glenn L. Hoffman

US Fish and Wildlife Services

E. W. Surber

Branch of US Federal Aid

Follow this and additional works at: https://digitalcommons.unl.edu/usfwspubs

Part of the Aquaculture and Fisheries Commons

Davis, H. S.; Hoffman, Glenn L.; and Surber, E. W., "Notes on Sanguinicola davisi (Trematoda: Sanguinicolidae) In the Gills of Trout" (1961). US Fish \& Wildlife Publications. 102.

https://digitalcommons.unl.edu/usfwspubs/102

This Article is brought to you for free and open access by the US Fish \& Wildlife Service at DigitalCommons@University of Nebraska - Lincoln. It has been accepted for inclusion in US Fish \& Wildlife Publications by an authorized administrator of DigitalCommons@University of Nebraska - Lincoln. 


\title{
NOTES ON SANGUINICOLA DAVISI (TREMATODA: SANGUINICOLIDAE) IN THE GILLS OF TROUT
}

\author{
H. S. DAvis* \\ Prepared from Dr. Davis' notes by \\ G. L. HoffmaN \\ Bureau of Sport Fisheries and Wildlife, Eastern Fish Disease Laboratory, \\ Leetown (P.O. Kearneysville), W. Va. \\ and \\ E. W. Surber \\ Bureau of Sport Fisheries and Wildlife, Branch of Federal Aid, \\ Peachtree-Seventh Building, Atlanta 23, Ga.
}

In 1953 the late Dr. Davis recorded the presence of an unnamed trematode from the gill blood vessels of fingerling eutthroat trout (Salmo clarki) and fingerling steelhead trout (Salmo gairdneri) at the Alsea Hatchery and in yearling rainbow trout (Salmo gairdneri) at the Oakridge Hatchery, both of the Oregon State Game Commission. Subsequently, two blood flukes, Sanguinicola davisi and S. kilamathensis, were deseribed from trout by Wales (1958). The present species was deternined to be $S$. davisi by one of us (GLH). This report supplements data reported by Davis (1953) and Wales (1958). Unfortunately, Dr. Davis' illustrations for the present paper could not be found.

While Dr. Davis was exanining the gills of fingerling cutthroat trout, he noticed numerous peculiar bodies in the capillaries which resembled superficially the vegetative state of a myxosporidian. However, the true nature of the organism remained in doubt until several months later when free-swimming miracidia emerged from the gills. Later, several adult worms were found in the arteries of the gill arches where they were difficult to find because of their small size and number. Although only certain stages of the life-cycle were available for study, it is believed that the information at hand regarding this remarkable worm is of sufficient interest to justify publication at this

Receiverl for publication Norember 22, 1960.

* The late H. S. Davis was formerly Fish Pathologist In-charge, Aquiculture Investigations, U. S. Fish and Wildlife Service, and author of "Culture and Diseases of Game Fishes." time.

In addition to cutthroat trout, the parasite also occurred in the gills of fingerling steelhead trout, Salmo gairdneri, at the same hatchery, but was not so abundant as in the cutthroat trout. An adult worm and cysts were found in the gills of a yearling rainbow trout from the Oakridge Hatchery. It is believed, on the basis of reports that reached Dr. Davis, that this parasite may occur in other species of trout and also young salmon, but this has not as yet been definitely determined.

\section{Description of the Adult Worm}

The adult worm was available for study only in sections. It has been found only in the arteries which extend from the heart to the gill arches and, owing to its minute size, it was very diffcult to find the worms by dissection of fresh material. This difficulty was increased by the fact that the adult worms were apparently not present in large numbers. It is described in Dr. Davis' notes as being strongly contractile and leaflike, resembling a typical planarian worm. It is very small, the largest observed being only about 650 microns in length. Another individual was 435 microns long, 110 microns wide, and with a maximum thickness of about 55 microns. Numerous spines are present in the body wall along each side of the body.

The mouth at the anterior end opens into the esophagus which is dilated and resembles a pharynx. It is separated by a constriction from the rest of the alimenary canal which extends as a slender tube for some distance and then expands to form a sac-like structure constricted in the niddle. The wall of the canal is moder- 
ately thick, but there is no indication of a cellular structure other than the presence of an occasional nucleus.

The irregular-shaped testes lie near the middle of the body and can be easily distinguished by the large numbers of thread-like spermatozoa interspersed with germ cells in various stages of development. The vas deferens follows a sinuous course from the testes to the external opening at the posterior end. The posterior twothirds of the semnial vesicle is lined with large conspicuous cells containing coarse granules that stain deeply with eosin. It was impossible to determine if a cirrus was present. Both genital openings are close together in a shallow groove near the posterior end of the body.

The ovary is convoluted just posterior to the testes. The oviduct is at first small, thinwalled, and difficult to distinguish, but after being joined by the vitelline duct it expands into a sac-like organ constricted in the middle. This sac extends posterior then doubles on itself to reach the genital pore. The vitellaria are distributed throughout most of the body and fill much of the space not occupied by the testes and ovary.

The excretory vesicle was not determined. The protonephridia described by Wales (1958) for this worm may be the excretory vesicle.

\section{The Ovum and Micracidium}

The entire development of the micracidia takes place in the gills where they form eysts within the capillaries. Since the adult worms live in the ventral aorta and branchial arteries, the eggs when deposited in the circulating blood are carried directly to the gills where most of them become lodged in the capillaries. A few may continue their development attached to the walls of the large blood vessels. At this stage they might easily be confused with the trophozoite stage of myxosporidea. Two relatively large vitelline cells became associated with each primary oocyte so closely that cell outlines were indistinguishable. The nucleus of the oocyte can, however, be easily distinguished by its considerably larger size and large central plasmosome. Each vitelline cell nucleus contains a smaller and usually eccentric plasmosome. Both types of nuclei have a well defined chromatic network. There is no shell around the egg as in other species of Sanguinicola. The zygote passes through the early cleavage stages rapidly but the vitelline cells do not divide for some time and can be easily recognized as two large cells which are attached to opposite sides of the embryo. In it the cytoplasm surrounding the nuclei is clear and stains more deeply than in the vitelline cells.

The further history of the two types of cells is difficult to trace. Both types multiply by mitoses but the vitelline cells are always sharply set off from the embryo and take no part in its development except to act as nurse cells. Their principal function is to form the wall of the "eyst" in which the miracidium develops. Differences between the vitelline cell nuclei and those of the embryo become even more striking. The latter vary greatly in size and structure while the vitelline cells become flattened to form the "cyst," a continuous layer one cell thick around the growing embryo.

The miracidium in its "cyst" is ovoid and may be conical at one end. The length of the miracidia preserved in formalin was 33 to 37 microns and the width 24 to 27 microns. Its surface bears long cilia, apparently uniformly distributed and is marked with fine longitudinal striations. The most striking change, however, is in the absence of most of the nuclei which were present in younger embryos but which apparently disappear as development proceeds; only 20 nuclei remain, 18 in a rounded mass of denser protoplasm at one end of the miracidium and just anterior to them two small nuclei. The most conspicuous feature of the living miracidium is the pigmented "eye spot" which is median and just anterior to the nucleated mass.

At the conical anterior end of the body is a stylet which extends into the body at an angle and ends near the "eye spot." The stylet stains only faintly with Ehrlich's hematoxylin but intensely with iron hematoxylin. In cross section it appears to be a flattened tube, tapered somewhat toward the rounded anterior end. Its wall has several longitudinal thickenings which stain more deeply than the remainder and have the appearance of the longitudinal bands described in Sanguinicola inermis by Plehn (1924). At the anterior end of the stylet, the protoplasm appears to be clearer and stains more deeply which may indicate the presence of contractile elements. The stylet probably is extended a short distance from the body when in use. Plehn thought that the stylet of $S$. inermis was used for piercing the egg shell, but since the "cyst" 
in $S$. davisi is soft and easily separated, it appears probable that the stylet functions primarily in penetrating the tissues of the snail host.

The "cyst" wall is separated from the miracidium by a narrow space and varies in thickness, but as the miracidiun matures it becomes considerably thinner. It contains three types of nuclei, the most conspicuous being a number of large flattened nuclei, oval in section and containing a large plasmosome in addition to the chromatin network. There are also several rounded nuclei filled with coarse chromatin granules, but without a plasmosome. Two of these are usually larger than the others, and are located close together and are surrounded by granular cytoplasm. The third type of nucleus is small, greatly elongated and in various stages of degeneration. It is probable that these are nuclei of endothelial cells which have become closely attached to the "cyst" wall. The "cysts" vary somewhat in size with an average length of 40 microns and a width of 27 to 30 microns in fixed material. The miracidium emerges by rupturing the "cyst" wall at one end.

\section{Effect on the Host}

There is no evidence that the adult worms materially injure the host. They are so minute and occur in such small numbers that they have little if any effect on the blood vessels or blood. The developing miracidia, however, may cause serious injury to the gills and often heavy mortality among infected fingerlings. A few embryonic stages in the gills are of little consequence but, where abundant, as they frequently are, it is a very different story. Since the adult worms evidently deposit large numbers of eggs in the blood stream, the presence of even two or three worms may result in the gills becoming fairly riddled with embryos in various stages of development. It is by no means exceptional to find several embryos in a single lamella, resulting in breakdown of gill tissues. Heavily infected fish are also noticeably anemic (Method of determining anemia was not stated).

Evidently, an occasional egg is carried past the gills since a few embryos are found in the kidneys, spleen, and even in the walls of the heart but may never be so abundant in such organs as to cause appreciable injury. Moreover, such embryos are in a blind alley as far as their future development is concerned and most of those observed were in various stages of disintegration.

\section{SUMMARY}

The blood fluke, Sanguinicola davisi, was found in the blood vessels of the gill arches of Salmo clarki and Salmo gairdneri in Oregon. The development of the miracidium and its associated "cyst" is described. Heavy mortalities resulted from the damage done to the gills by the presence of the developing miracidia.

\section{ACKNOWLEDGMENT}

Dr. F. G. Wallace, Zoology Department, University of Minnesota, Drs. S. F. Snieszko and Ken Wolf, Eastern Fish Disease Laboratory, Leetown (P.O. Kearnesyville), West Virginia have kindly read the manuscript.

LITERATURE CITED

DAvis, H. S. 1953 Culture and Disease of Game Fishes. Univ. Calif. Press, Berkeley. 352 pp. PlehN M. 1924 Praktikum der Fischkrankheiten. E. Schweizerbart, Stuttgart. 179 pp.

Walfs, J. H. 1958 Two new blood fluke parasites of trout. Calif. Fish and Game 44: 125136. 